\title{
State of Municipal Finance in Commonwealth Developing Countries
}

\section{Background}

It is expected that most of the increase in the world's population until 2030 will be absorbed by urban areas. In sub-Saharan Africa, the urban population, 270 million at the time of writing, has increased at an annual rate of about 5 per cent since 1980 and is expected to reach 630 million by 2030. Over a similar period, the urban population in Asia will rise from 1,570 million to 2,670 million. As urban growth continues unabated, an increasing number of Commonwealth (developing) countries have assigned greater autonomy and responsibility for infrastructure and service provision to local governments. The unprecedented urbanisation coupled with the growth in population presents a challenge to government authorities in providing adequate infrastructure facilities and services.

Where local governments are mandated with infrastructure provision such as roads, water, sanitation, primary healthcare and education, they face a number of constraints in maintaining and expanding the network of services. Growing fiscal deficits at all levels of government constrain the funds available for the provision of infrastructure and public services. The infrastructure demands as a result of decentralisation and urban growth often overpower the local authorities' financial and institutional capacity. For example, in Africa and Asia, up to 50 per cent of the urban population do not have adequate water supplies and about 60 per cent lack adequate sanitation. A concerted effort is needed by local governments to address present and future demands for municipal infrastructure financing and service provision. ${ }^{1}$

\section{Sources of municipal finance}

The concept that 'finance follows function' is enshrined in political decentralisation mandates across the world. However, in practice, the extent of fiscal decentralisation has not kept pace with administrative and functional decentralisation in most developing countries. 
The theory of fiscal federalism assigns the public finance role of resource allocation to local governments, while retaining the roles of economic growth and income distribution at the federal level. Accordingly, only immobile tax bases such as property taxes are typically assigned to local jurisdictions. ${ }^{2}$ These tax bases, by definition, are less elastic to economic growth and are hence limited in their expansive ability. The matching principle of local finances emphasises that the financial capacity of local authorities should be harmonised with the functional responsibilities assigned to them. To that effect, operational expenditures are typically expected to be met by locally raised revenues, and capital expenditures are financed by intergovernmental transfers, grants and external funds. ${ }^{3}$ Historically, borrowing at the local level has not been favoured, as the traditional thesis of capital financing professed that local government borrowing is irresponsible and not viable and sustainable given its poor income generation capacities. ${ }^{4}$ This thinking was embedded in donor policies of lending to sovereigns and not to local bodies.

However, these conventional theories have been challenged by the recent trends of urbanisation and globalisation, which have heightened the pressure on cities' growth and infrastructure. Simultaneously, political decentralisation strategies have pushed downwards to city governments the responsibility for coping with the explosive demand for urban services. ${ }^{5}$ In comparison, financial authority is being devolved gradually, owing to political unwillingness to delegate power to local entities, as well as genuine fiscal inability at all levels to finance the spiralling urban infrastructure requirements. ${ }^{6}$

The varied pace of fiscal decentralisation across countries and the differences in sizes and economic prospects of cities have resulted in a wide diversity of sub-national fiscal structures across developing and emerging market countries. Some cities that are engines of economic growth generate a high degree of own-source revenues and in turn contribute to the central exchequer. However, as a general principle, the own-source revenues of most cities are not very substantial and primarily comprise immobile tax sources such as property tax. Table 2.1 summarises the typical tax bases by level of government.

Globally, local revenue sources include tax and non-tax charges, and transfers from the higher levels of government. Depending on the country being examined, tax

Table 2.1. Tax base

\begin{tabular}{lll}
\hline Level of government & Tax base & Tax base mobility \\
\hline Central & Capital income & High \\
Intermediate (state/provincial) & Consumption/labour income & Medium \\
Local/municipal & Real property & Low \\
\hline
\end{tabular}

Source: Ebel and Vaillancourt (2001) 
revenues include personal and corporate income tax, property tax, and tax on goods and services. Non-tax revenues comprise fees, fines and user charges.

Table 2.2 provides an un-weighted average summary of local revenues across groups of countries or regions over the period 1991-2001. ${ }^{7}$ The key observations are:

- Developing countries in Asia and Africa are still lagging behind in terms of percentage contribution of local revenues to overall government revenues as well as the percentage of own revenues (vis-à-vis transfers and grants) in total local revenues. This indicates that the pace of financial decentralisation in developing countries is as yet gradual.

- Also, income taxes typically constitute a large proportion of local revenues in the OECD, East European and transition countries. Developing countries across South and Central America, Asia and Africa, on the other hand, derive most of their own local revenues from property taxes and taxes on goods and services.

- Local governments in South and Central America in particular derive almost a quarter of their tax revenues from transactions, especially in goods and services. These tax sources are economically more buoyant than property taxes.

- Non-tax sources such as fees, fines and charges supplement the local government's own revenues.

The efficient administration and collection of the assigned local revenue sources depends, in part, on the strength of the institutional structures of the local governments. Several local governments in developing countries that enjoy some degree of administrative and financial strength have been trying to increase their traditional revenue sources as well as to mobilise alternate, including private, financing.

Table 2.2. Local government revenues (un-weighted average across sampled countries)

\begin{tabular}{|c|c|c|c|c|c|c|c|}
\hline Countries & $\begin{array}{l}\% \text { local } \\
\text { revenues }\end{array}$ & $\begin{array}{l}\% \text { own } \\
\text { revenues }\end{array}$ & $\begin{array}{l}\% \text { tax } \\
\text { revenues }\end{array}$ & $\begin{array}{l}\% \\
\text { income } \\
\text { taxes }\end{array}$ & $\begin{array}{l}\% \\
\text { property } \\
\text { taxes }\end{array}$ & $\begin{array}{l}\% \text { goods } \\
\text { and service } \\
\text { taxes }\end{array}$ & $\begin{array}{l}\% \text { non-tax } \\
\text { revenues }\end{array}$ \\
\hline OECD & 14.8 & 63.8 & 42.2 & 20.7 & 13.1 & 5.2 & 9.9 \\
\hline $\begin{array}{l}\text { Eastern Europe } \\
\text { and transition } \\
\text { countries }\end{array}$ & 19.6 & 70.2 & 55.4 & 33.9 & 6.8 & 11.3 & 7.3 \\
\hline $\begin{array}{l}\text { South and } \\
\text { Central America }\end{array}$ & 7.1 & 68.8 & 47.2 & 2.3 & 13.4 & 22.7 & 5.3 \\
\hline Asia/Africa ${ }^{8}$ & 6.9 & 58.5 & 32.8 & 3.0 & 13.7 & 13.8 & 7.6 \\
\hline
\end{tabular}

Source: Ebel and Vaillancourt (2001), IMF (2002) ${ }^{9}$ 


\section{International experience on alternate sources of financing}

Several developing country governments are trying to bolster their traditional sources of municipal finance by mobilising alternate market-based sources of funding. The typical options exercised have been borrowing from financial institutions and development banks, accessing capital markets, or soliciting private sector participation through contracts, leases and concessions. However, municipal urban services like water supply and sanitation, sewerage and solid waste management do not prove attractive to private financiers given their characteristics of time and space externalities, limited cost recovery, high risk and long gestation investments. Furthermore, few municipal governments in developing countries have a strong financial position, and their projects are most often not commercially viable. On the supply side, banks and financial institutions are constrained by their balance sheet and are willing to offer only shorter tenure loans, typically up to 5-7 years, and often require sovereign guarantees for local lending.

In contrast, sub-national governments of North America and Western Europe hold a long-standing record of harnessing private debt for urban infrastructure. The credit models championed by these blocs are instructive in their diversity - while North America relies mainly on municipal bonds, Western Europe has developed its homegrown municipal banks. Emerging markets are attempting one or a hybrid of the above models, either directly or through specialised financial intermediaries or municipal funds. ${ }^{10}$

The US municipal bond market originated to cater to the urban boom of the 1850 s. Specific purpose revenue bonds have matured into the primary source of funding capital projects, but general obligation bonds issued against the full faith of local government revenues are also prevalent. The federal government has endorsed decentralised financing by conferring tax-free status to municipal bonds, and contributing to State Revolving Funds and Bond Banks. These intermediaries pool the borrowing needs of marginal local entities that are unable to individually access capital markets. ${ }^{11}$ A mature federal system comprising strong sub-national governments matched with an enabling investment environment has promoted the growth of US municipal debt markets.

Western Europe, on the other hand, leveraged its historic preferential access to long-term saving deposits and government contributions to establish municipal banks and financial institutions. Examples of municipal banks include Dexia Credit Local of France, BNG of Netherlands, Banco de Credito of Spain and Credit Communal Belgique of Belgium. With financial deregulation, some of these banks are also converging into the competitive capital markets to raise funds. ${ }^{12}$

Developing country governments have attempted to access market-based financing by creating municipal development funds (MDFs), often with the backing of international agencies and development finance institutions. However, developing 
self-sustaining local credit markets has proved challenging. The pioneering MDF in Brazil provides loans to municipalities and special utility companies and enjoyed over 30 years of commendable loan recovery rates and less than 5 per cent nonperforming loans. ${ }^{13}$ The Infrastructure Finance Corporation Limited in South Africa also provides loans to municipalities and other statutory boards and utilities. Similarly, since 1996 Vietnam has established several provincial Local Development Investment Funds (LDIFs), in order to develop infrastructure and enable mobilisation of private capital and participation in these projects. India has also successfully established several state-level municipal or urban development funds that have raised market financing for sub-national infrastructure projects.

Several Indian municipalities have also raised bond financing in the recent past, and some of them, such as the Ahmedabad Municipal Corporation in the western state of Gujarat, have obtained investment grade credit rating to reduce the cost of bond issues. Zimbabwe has also issued municipal bonds with sovereign guarantees. ${ }^{14}$ Low domestic savings have motivated some cities like Sofia in Bulgaria and Moscow and St Petersburg in Russia to float foreign bonds. ${ }^{15}$

The other successful model has been that of a contingent financier, which provides products such as guarantees or insurance that are contingent to the main project financing. FINDETER in Columbia, established in 1989 as a second-tier government financial intermediary, rediscounts bank loans to local borrowers. It has motivated commercial banks to be responsible for municipal credit risks across sectors such as transportation, water and sewerage, and education. ${ }^{16}$ Another example is the Local Government Unit Guarantee Corporation (LGUGC) in the Philippines. Initiated as the brainchild of the Department of Finance in 1997, LGUGC provides insurance to municipal investors. It is uniquely structured as a jointly owned public-private entity, supplemented by a 30 per cent US Agency for International Development (USAID) backed credit guarantee. It has also instituted a proprietary credit rating system to identify creditworthy issuers. ${ }^{17}$

Some of these examples are described in greater detail in chapter 7 of this book. Nonetheless, the above summary indicates that no decentralised municipal system is dependent on a single borrowing option for all infrastructure needs. While many governments have instituted MDFs to front-end inexperienced local borrowers, several have matured into a multi-tiered municipal credit system. Larger creditworthy local entities access cheaper bond finance against their own balance sheet, while small and medium entities continue to leverage financial intermediaries, development banks, and government grants. Often, a line of credit or credit enhancement from a contingent financer and/or an international financial institution has proved instrumental in extending the maturities of local debt instruments.

Against this overview, the following chapters of the book provide detailed case studies on municipal finances in four selected Commonwealth cities. This is then 
followed by a description of some alternate techniques of innovative financing of municipal infrastructure and services.

\section{Notes}

1. United Nations (2006); Dirie (2006).

2. Musgrave (1959); Oates (1993).

3. Bird (2001).

4. Bahl (1981).

5. Vera and Kim (2003).

6. Bird (1980); Bahl and Linn (1992).

7. The percentage of local revenues in the second column of the table refers to the contribution of locally raised revenues in the national revenues. All other percentages in the table represent that particular source of income as a proportion of the total local revenues.

8. India and China are not included in the countries studied. Average excludes Zimbabwe.

9. Incorporates own calculations using base data, Netherlands Antilles has been excluded as it is non-representative of the rest of the region.

10. Peterson (2003).

11. El-Daher (1997).

12. Peterson (1996); El-Daher (2000).

13. Peterson (2003).

14. Phelps (1997).

15. Marfitsin et al (1997); Epstein et al (2000).

16. Kehew et al (2005); Peterson (2000).

17. USAID (1997); Orial (2003). 